\title{
Looking back to 2009 and ahead to 2010
}

\author{
Almut B. Heinrich • Ulrich Förstner
}

Received: 19 November 2009 / Accepted: 19 November 2009/Published online: 19 December 2009

(C) Springer-Verlag 2009

Dear Subscribers, Authors, Editors, Referees, and all Readers,

\section{Increase in frequency}

This January 2010 issue begins our 10th year of publishing "Journal of Soils and Sediments/Protection, Risk Assessment and Remediation" (JSS). We are very pleased to let you know that, due to the generosity of Dr. Paul Roos, Editorial Director for Springer's Environmental Sciences, we can increase the frequency of our journal, i.e. we shall publish eight issues instead of six. The page budget amounts to 120 pages per issue. The editions appear midmonth in January, March, April, May, July, September, October and December. The increase in frequency became necessary due to the high number of submissions and will allow us to publish the online articles in a timely manner in the printed journal as well.

Responsible editor: Almut B. Heinrich

A. B. Heinrich $(\bowtie)$

Scientific Journals,

Kirschgartenstr. 91,

69126 Heidelberg, Germany

e-mail: ABH.scientificjournals@googlemail.com

U. Förstner

Institute of Environmental Technology and Energy Economics,

Hamburg University of Technology,

Eissendorfer Str. 40,

21071 Hamburg, Germany

e-mail: u.foerstner@tu-harburg.de

\section{Publications in 2009}

In 2009, we published six issues with 66 articles and 663 pages. The authors originated from almost all over the world:

1. Australia

2. Belgium

3. Brazil

4. Canada

5. China

6. Denmark

7. Egypt

8. England

9. Finland

10. France

11. Germany

12. Hong Kong

13. Iran

14. Israel

15. Italy

16. Lithuania

17. New Zealand

18. Pakistan

19. Poland

20. Portugal

21. Russia

22. Slovak Republic

23. Spain

24. Sweden

25. Taiwan

26. Thailand

27. The Netherlands

28. USA

29. Uzbekistan 
This list demonstrates that, in the course of the past 9 years, JSS has become a truly international journal.

\section{Articles in online first}

Currently, we have 36 articles published online. They will appear in the printed journal in 2010. However, in order to cite them, you need not wait for the printed issue. You can cite the online articles via the DOI.

\section{Articles in Springer's submission system, the editorial manager}

At the beginning of 2009, JSS adopted Springer's Editorial Manager System (http://jsss.edmgr.com/). It is more flexible than the former ESS and easier to handle. Currently, 73 submissions are on their way through the review process. Even at an acceptance rate of approximately one third of the original submissions, our extrapolations from the 2009 figures and under consideration of the online articles, we expect a $30 \%$ increase in the number of accepted papers for the 10 th volume.

\section{Thematic issues in 2009 and 2010}

Number 4, the August issue in 2009, presented a thematic set of eight articles under the title Urban Sediments: a Global Perspective, edited by Kevin G. Taylor and Philip N. Owens - both of them are subject editors for the area "Sediments" in JSS:

- Horowitz AJ (2009) Monitoring suspended sediments and associated chemical constituents in urban environments: lessons from the city of Atlanta, Georgia, USA. Water Quality Monitoring Program. J Soils Sediments 9(4):342-363

- Irvine KN, Perrelli MF, Ngoen-klan R, Droppo IG (2009) Metals levels in street sediment from an industrial city: spatial trends, chemical fractionation, and management implications. J Soils Sediments 9(4):328-341

- Krčmová K, Robertson D, Cvečková V, Stanislav R (2009) Roaddeposited sediment, soil and precipitation (RDS) in Bratislava, Slovakia: compositional and spatial assessment of contamination. J Soils Sediments 9(4):304-316

- Poleto C, Bortoluzzi EC, Charlesworth SM, Merten GH (2009) Urban sediment particle size and pollutants in Southern Brazil. J Soils Sediments 9(4):317-327

- Schäfer J, Norra S, Klein D, Blanc G (2009) Mobility of trace metals associated with urban particles exposed to natural waters of various salinities from the Gironde Estuary, France. J Soils Sediments 9(4):374-392

- Taylor KG, Owens PN (2009) Preface. J Soils Sediments 9 (4):279

- Taylor KG, Owens PN (2009) Sediments in urban river basins: a review of sediment-contaminant dynamics in an environmental system conditioned by human activities. J Soils Sediments 9 (4):281-303

- Xu W, Zhang G, Wai OWH, Zou S, Li X (2009) Transport and adsorption of antibiotics by marine sediments in a dynamic environment. J Soils Sediments 9(4):364-373

In 2010, three thematic issues are on the way.

1. Sediment Management in Norway is a thematic set of six articles edited by Gijs Breedveld, subject editor for the area 'Sediments' in JSS. The issue will appear in April or May. In central Europe, sediment management has been an issue for many decades, but in Norway this field is rather new. The reason is that sedimentation rates are generally low, in the order of millimetres per year, and the need for navigational dredging has therefore been limited. The Norwegian coast is dominated by deep fjords with limited circulation of the water column. As a result, contaminants from industrial and urban activities have been accumulating in the fjords since early industrialisation.

Sequence of papers

1. Contaminants in urban runoff to Norwegian fjords Morten Jartun and Arne Pettersen

2. Freely dissolved PCDD/F concentrations in the Frierfjord, Norway: Comparing equilibrium passive sampling with 'active' water sampling

Gerard Cornelissen, Dag Broman, and Kristoffer Næs

3. Development of sediment quality criteria in Norway Torgeir Bakke, Torsten Källqvist, Anders Ruus, Gijs Breedveld, and Ketil Hylland

4. Sorption of native perfluorinated compounds in river water to activated carbon at environmentally relevant concentrations

Mona C. Hansen, Marion Børresen, Martin Schlabach, and Gerard Cornelissen

5. Valuing the benefits of large scale remediating contaminated marine sediments - a review and illustration from the Grenlandsfjord Norway

David. N. Barton, Ståle Navrud, Heid Bjørkeslett, and Ingrid Lilleby 
6. Sediment and society: an approach for assessing management of contaminated sediments and stakeholder involvement in Norway

Amy M.P. Oen, Magnus Sparrevik, David Barton, Udaya Sekhar Nagothu, Gerald Jan Ellen, Gijs D. Breedveld, Jens Skei, and Adriaan Slob

2. Sediment Response to Catchment Disturbances is a thematic set of six articles edited by Philip N. Owens, Ellen Petticrew and Marcel van der Perk. The three of them are subject editors for the area "Sediments" in JSS. The issue will appear in May or July.

Sequence of papers

1. Slaymaker O: Drivers of change in mountain environments during the twenty-first century

2. Slattery M, Phillips JD, Todd L, Breyer J: Fluvial sediment delivery and human impact in a large coastal plain river: The case of the Trinity River, Texas

3. Byrne P, Reid I, Wood PJ: Sediment geochemistry of streams draining abandoned lead/zinc mines in central Wales - the Afon Twymyn
4. Middelkoop H, Erkens G, van der Perk M: The Rhine Delta - a record of sediment trapping over time scales from millennia to decades

5. Vanmaercke M, Zenebe A, Poesen J, Nyssen J, Verstraeten G, Deckers J, Govers G: Magnitude and dynamics of sediment export in the Northern Ethiopian Highlands

6. Neary DG, Smethurst PJ, Baillie BR, Petrone KC: Does tree harvesting in streamside management zones increase stream sedimentation and turbidity? - an Australian case study

3. The International Symposium of Molecular Environmental Soil Science at the Interfaces in the Earth's Critical Zone (ISMESS 2009) was successfully held in Hangzhou, China, from 10 to 14 October 2009.

Prof. Zhihong Xu, the Editor-in-Chief for the area 'Soils' in JSS, recommended to develop a thematic set of around 20 papers from this conference, with Jianming Xu, Caixian Tang, and Jizheng He (subject editors for the area 'Soils') as guest editors. The issue is planned to appear in the second half of 2010 . 